\title{
Increasing writing skill of narrative and motivate students class IV primary school through environment approach
}

\author{
Richi Viodelf ${ }^{1}$, Syahrul², Yalvema Miaz ${ }^{3}$ \\ ${ }^{123}$ Universitas Negeri Padang, Padang - Indonesia, (viodelfrichi@gmail.com)
}

\begin{abstract}
Based on early observation and teaching experience in grade IV student of SDIT Mutiara Hati Payakumbuh, finding writing skill of narrative in grade IV is low. For that need to improvement for help student in writing of narrative by correct stage. The research purpose to explain the process, result and motivate of learning writing skill by environment approach. The kind of the research is class action research through environment approach. Based on the result of research, using environment approach in learning writing student skill of narrative proved can increase writing skill of student. Increasing average in result of learning at pre cycle student writing skill of narrative by average $69,82 \%$. After did action increase skill become $80,5 \%$ at phase II student writing skill increase become $87,5 \%$, writing of narrative through environment approach proved can motivate student by result of questionnaire by student, as many $58,3 \%$ student always want to study by environment approach and around $29,2 \%$ hope more after study through environment approach.
\end{abstract}

Keywords : writing narrative, environment approach.

\section{Introduction}

Writing is an activity that can not be separated from the activities of human life. Writing is an activity of indirect communication in the form of delivery of written message to other party. Skills that must be owned by elementary school students of class IV one of them is writing narrative (kisahan). Suparno (2006: 4.54) suggests narration is a writing that presents a series of events. Narrative writing aims to provide information or provide insight and expand knowledge, and provide an aesthetic experience to the reader.Narrative writing skills are important for students because writing narratives can convey events or events in everyday life chronologically. With Indonesian language lessons, students are expected to be able to communicate in Indonesian language which is good, correct, coherent, and effective, both oral and written. Because the essence of language learning is learning communication. Writing skills is an important factor in communication. As Hennes, (2015: 40) explains: Sutri (2015) explains: "A student would not be skilled at writing if he only possessed one or two components between the three components.

How many students master the Indonesian language in writing, but can not produce writing because they do not know what to write and how to write it. How many students who know many things to write and also know to use written language but can not write because do not know how. 
Writing is not a difficult job but also not easy, to start writing, every writer does not have to wait to become a skilled writer. Learning the theory of writing is easy, but to practice it is not enough once or twice. The frequency of writing exercises will make a person skilled in writing. "It is clear that writing skills have a major impact on education, especially literary societies. Because writing can help to create, store, communicate knowledge, build communication, and as a basis for generating decisions. The teaching of writing should be made more meaningful for the students.

In addition to providing theories about writing to students in the learning process, it is also necessary to provide motivation that can stimulate students to be able to write. Someone who has no motivation to learn, will not be possible to carry out learning activities. The necessary natural motivation determines the intensity of the learning effort for the students. Rukayah (2014: 2) explains: "Motivation is a basic impulse that drives a person to behave. The word motivation comes from the word motif which means the power contained within a person and cause the individual to perform an action ". In line with the opinion above Hamdu, G., and Agustina, L. (2011: 91) states:"Motivation is one of the things that affect the success of student learning activities. Without motivation, learning process will be difficult to achieve optimum success ". In line with the above statement John Mark Froiland, (2012: 98), states: Praise is the positive reinforcer that has the potential to elevate both intrinsic motivation and extrinsic motivation. Although tangible rewards may be necessary to help some of the positive synergy with intrinsic motivation.

Based on the problems described previously needed the right way to the previous problem. Researchers choose the right approach and implement correctly can increase the interest and enthusiasm of students in following the learning process, so that students are active in the learning process. The environmental approach is one deep approach a suitable Indonesian lesson learned in narrative writing. The fourth graders of SD are still in concrete operational times, and still need real objects to develop their imagination in writing. As explained by Mulyasa (2015: 101) learning by environmental approach means students gain knowledge and understanding by observing themselves what is in the environment, both in the home and school environment.

\section{Method}

This research is a type of Classroom Action Research (PTK). Research method is basically a scientific way to get data with a specific purpose and usefulness. According Sanjaya (2009: 33) PTK depart from the unrest experienced by teachers in the management of the learning process, therefore, from the start of the planning process, implementation of until action in the teacher inference process is the main character. Further Muslich (2009: 10) mentions PTK aims to improve and improve the quality of learning and help empower teachers in solving learning problems in schools.

A PTK is a reflection of a learning activity in the form of an action, which is deliberately raised and occurs in a class together. The action is given by the teacher or direction of the teacher by the student. Arikunto (2007: 11) presents four main steps in classroom action research, (1) planning, (2) implementation, (3) observation, and (4) reflection. Data Collection Tool in the form of student worksheets, Questionnaire is a number of questions used to obtain data from students. Observation by observation sheets can be referred to as assessment tools performed to measure individual behavior or the process of occurrence of an observed activity. During the learning process, teachers are observed by the observer, and then discussed after the learning is completed for improvement for further learning. Teachers are observed by peers or collaborators in learning activities. Arikunto (2009: 127) suggests that observation is an activity of observation (data collection) to monitor how far the effect of action has reached the target. Next guidelines for interview and documentation.

This research was conducted at SDIT Mutiara Hati Payakumbuh. The selection of research sites is based on the consideration that the authors in this school as a classroom teacher and willing to try to 
make renewal, especially in efforts to improve the quality and quality of student learning. The subjects of the study were fourth grade students of SDIT Mutiara Hati Payakumbuh. The number of students was 24 students who were all women.

According Warsidi (2009: 76) there are several steps to write a narrative through the environmental approach. Pre writing, (a) Students listen to the teacher's explanation of writing a narrative paragraph through an environmental approach. (b) Students and teachers ask questions about narrative paragraphs (c) Students pay attention to examples of narrative text the teacher displays on the blackboard, (d) Students listen to teacher's explanation of the correct way of writing through an example of the narrative text the teacher shows on the board.

When writing, (a) Students are invited out of the classroom to continue the lesson. Students guided teachers determine topics by observing many objects. (b) Students are supervised by the teacher to write a written framework on the chosen topic. (c) Students are given examples of how to develop a writing framework into a complete and coherent narrative script with design to several objects around the school environment. (d) Students develop written skeletons into full and coherent writing. Post writing, (a) The student returns to the class. (b) Students are guided to exchange their writing with their on-board friends. (c) Students under the guidance of the teacher revise the contents of his friend's writing. (d) Students under the guidance of teachers make edits to the writing of their friends by paying attention to the choice of words and use of spelling carefully and thoroughly. (e) The student returns his revised writing. (f) Students under the guidance of teachers improve their writing. (g) Students with teacher guide to summed up the whole lesson with courage and confidence. (i) To be responsible about material that students have not understood. (j) Provide reinforcement and appreciation of student achievement.

\section{Results and Discussions}

The result of observation of narrative skill learning through environment approach. On pre cycle or before the action on the student implementation of learning conducted by teachers conducted by lecture method. Students are required to write a narrative essay based on a student handbook and do not use writing stages. Based on observations made, then the teacher needs to do improvement.In the first cycle, teachers interact with students to explore students' knowledge of narrative writing. Teachers introduce to students the environmental approach as an alternative to writing narrative . Teachers implement narrative writing lessons using the environmentschool. To write the narrative the teacher uses the writing stage (pre writing, writing, and post writing).

Based on the reflection of cycle I teachers make improvements. In cycle II the teacher gives motivation and appreciation to the students. To increase the spirit and provoke imagination and add ideas in writing narrative, teachers take advantage of the location of tourism near the school of Ngalau Indah. Teachers use writing stages (prewriting, writing, postwriting). Based on the purpose of this study, the following describes the comparative value of the results and the process of writing narrative through the environmental approach and the percentage table of students' perceptions of learning to write narrative through the environmental approach. 


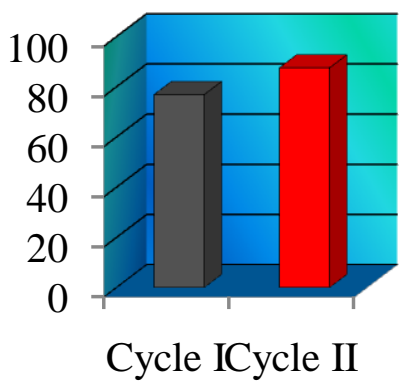

Picture 1. Diagram of Value Improvement Process of Narrative Writing on, Cycle I and Cycle II.

Comparison of process values and the results of narrative writing through the environmental approach are presented in Figures 1 and 2. In Figure 1 the bar chart is a percentage increase in the value of the process. Figure 2 presents a graph of increasing the value of narrative writing. Picture 1 shows the learning outcomes at the stage of narrative writing process with the increase of each cycle, in cycle I the process value is 76.86 and in cycle II there is an increase of $12.16 \%$ with the value of 87.50 .

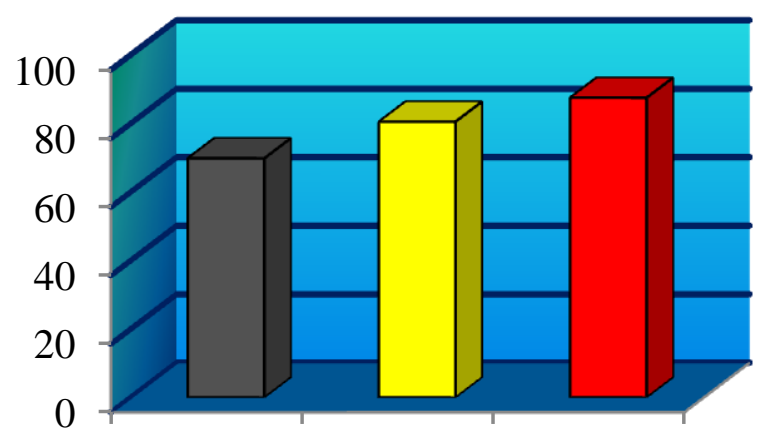

\section{Pre Cycle Cycle I Cycle II}

Picture 2. Improved Value Chart of Writing Narrative on Prasiklus, Cycle I and Cycle II.

Picture 2 shows the result of writing a narration with a value of 69.82 in the pre-cycle stage. The increase of narrative writing from pre-cycle to cycle I is $13.27 \%$ with the value of 80.5 and cycle II increased by $8.03 \%$ with a value of 87.53 .

The result of the questionnaire given about the students' perceptions on the learning of narrative writing through environmental approach shows that there is a considerable change of student perception. Responses to statements by respondents based on category groups experience changes. Based on the data that has been previously attached, it can be concluded that students' perceptions of the statements related to learning to write narrative through environmental approach can be accepted by students as an alternative to writing narrative writing, and an increase in student learning motivation on each item of statement submitted. A total of $51.5 \%$ of students responded always, $42.2 \%$ responded frequently and $28.2 \%$ responded occasionally to students. Means more than half of students have learning motivation in learning Indonesian especially learning narrative writing skills through environmental approach.

As explained by Mulyaningsih (2014: 445) the characteristics of students who are motivated to learn high will always work hard, tough, not easily despair, future oriented, enjoying tasks that have medium difficulty levels, and likes a quick feedback about his achievements are also responsible answer in solving the problem. Further Halimah (2008: 3) states the environment as an endless source of learning in providing knowledge to students. The more excavated the more students get. Agreed with Uno (2013: 137) that the environment is the most effective and efficient learning resources and 
does not require a large cost in improving students' learning motivation. Thus, the environment as a learning resource for students has economic value. Based on the above explanation can be summed up the environment as a source of learning that provides an inexhaustible supply of knowledge to students, the environment can help students to motivate the digging of knowledge from nature. Makes nature a source of inspiration in many ways such as in writing narrative . Many things students can write about the environment that provides everything for free and also practical.

\section{Conclusion}

Based on the actions that have been made to the learning of narrative writing skills through environmental approach in the fourth grade of SDIT Mutiara Hati, it can be concluded as follows. There has been an increase in the process of writing narrative through the environmental approach in the fourth grade of SDIT which can be seen from the results of the assessment of the student process. Improved process of narrative writing skills also supports the results of narrative writing skills. Improvement of assessment results starting from pre cycle, cycle I and cycle II can be seen through the writings of students who have accumulated according to the rubric of assessment of the results of narrative writing. Improvement is also seen in student learning motivation from cycle I to Cycle II which can be known through questionnaires that have been checked by students with some indicators that have been available. In addition, use

the environmental approach can also improve the positive attitude and behavior of students in the process of learning narrative writing, the students do the task enthusiastically, the students carry out the learning activities seriously, and students are happy to follow the learning process.

\section{Acknowlegment}

This research can be completed thanks to the help and guidance of various parties, on this occasion the researchers express their sincere thanks to counselor I and mentor II who has provided ease, take the time and provide guidance, motivation, spirit, and knowledge that is very useful for author in completing this research. To Contributors I, II and III who are always friendly in providing suggestions and inputs for the perfection of this research. To Head of Education Office Payakumbuh and principal of SDIT Mutiara Hati Payakumbuh which has allowed writer to do research. To collaborators and students who have worked well together. The author realizes that, with all the limitations of this writing is far from what is expected. Therefore, criticism and suggestions from all parties, especially the readers are expected to make this research more perfect. Finally the authors can only hope that this research can provide benefits especially in the development of classroom action research.

\section{References}

Arikunto, S. (2007). Prosedur Penelitian Suatu Pendekatan Praktik. Jakarta:Rineka Putra.

Hennes, A. K., Ozlem, B., Christian, R., dan Matthias, G. (2015). Helping children with specific learning disabilities to improve their narrative writing competence by teaching them to use the story maps strategy. International Journal of Education for Children. 12(1) hlm 35-56.

Hamdu, G., dan Agustina, L. (2011). Pengaruh motivasi belajar siswa terhadap prestasi belajar IPA di Sekolah Dasar (studi kasus terhadap siswa kelas iv sdn tarumanegara kecamatan tawang kota tasikmalaya). Jurnal Penelitian Pendidikan. 12(1).

John, M. F., Emily O., Liana S, B. S., \& Tyrell H. B. A. (2012). Intrinsic motivation to learn: the nexus between psychological health and academic succes. International Journal of Contemporary School Psychology. 16(1) Hlm 91-100. 
Mulyaningsih, I., E. (2014). Pengaruh Interaksi Sosial Keluarga, Motivasi Belajar, dan Kemandirian Belajar Terhadap Prestasi Belajar. Jurnal Pendidikan dan Kebudayaan. Vol. 20, nomor 4, hlm 441451. FKIP Universitas Veteran Bangun Nusantara Sukoharjo.

Mulyasa. (2015). Menjadi Guru Profesinal. Bandung: PT. Remaja Rosdakarya

Rukayah. (2014). The writing skill of 3th grade students of sibulue subdistrict junior high school of bone regency. International Journal of Linguistics. 6(2). Hlm 34-46

Sanjaya., W. (2009). Penelitian Tindakan Kelas. Jakarta: Kencana Pernada Media Group.

Suparno (2006). Keterampilan Dasar Menulis. Jakarta. Universitas Terbuka.

Sutri. (2015). Pembelajaran keterampilan menulis narasi dengan media gambar berseri pada siswa kelas iv sekolah dasar negeri palawad ii karawang timur. Jurnal Pendidikan Unsika. 3(1), 121-131.

Uno, H. B., Mohamad., N. (2013). Belajar dengan Pendekatan PAILKEM. Jakarta: PT. Bumi Aksara. 